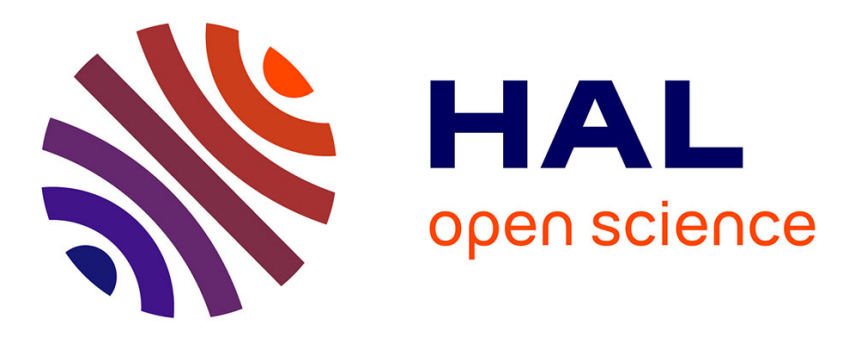

\title{
Wear property of ductile iron locally reinforced with Cr-containing steel inserts
}

\author{
Mayerling Martinez Celis, Nathalie Valle, Jacques Lacaze, Ingolfur
}

Thorbjornsson, Birgir Johannesson, Jon Thor Thorgrimsson, Bojan Pogornik, Joze Vizintin

\section{To cite this version:}

Mayerling Martinez Celis, Nathalie Valle, Jacques Lacaze, Ingolfur Thorbjornsson, Birgir Johannesson, et al.. Wear property of ductile iron locally reinforced with Cr-containing steel inserts. Key Engineering Materials, 2010, vol. 457, pp. 441-446. 10.4028/www.scientific.net/KEM.457.441 . hal00865736

\section{HAL Id: hal-00865736 https://hal.science/hal-00865736}

Submitted on 25 Sep 2013

HAL is a multi-disciplinary open access archive for the deposit and dissemination of scientific research documents, whether they are published or not. The documents may come from teaching and research institutions in France or abroad, or from public or private research centers.
L'archive ouverte pluridisciplinaire $\mathbf{H A L}$, est destinée au dépôt et à la diffusion de documents scientifiques de niveau recherche, publiés ou non, émanant des établissements d'enseignement et de recherche français ou étrangers, des laboratoires publics ou privés. 


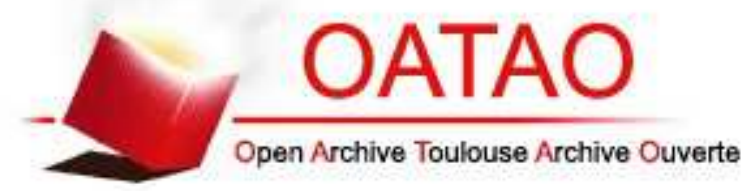

\section{Open Archive TOULOUSE Archive Ouverte (OATAO)}

OATAO is an open access repository that collects the work of Toulouse researchers and makes it freely available over the web where possible.

This is an author-deposited version published in : http://oatao.univ-toulouse.fr/ Eprints ID : 5860

To link to this article : DOI: 10.4028/www.scientific.net/KEM.457.441

URL : http://dx.doi.org/10.4028/www.scientific.net/KEM.457.441

To cite this version : Martinez Celis, Mayerling and Valle, Nathalie and Lacaze, Jacques and Thorbjornsson, Ingolfur and Johannesson, Birgir and Thorgrimsson, Jon Thor and Pogornik, Bojan and Vizintin, Joze. Wear property of ductile iron locally reinforced with Cr-containing steel inserts. (2010) Key Engineering Materials, vol. 457 .pp. 441-446. ISSN 1013-9826

Any correspondance concerning this service should be sent to the repository administrator: staff-oatao@ listes-diff.inp-toulouse.fr 


\title{
Wear property of Ductile Iron Locally Reinforced with Cr-Containing Steel Inserts
}

\author{
Mayerling Martinez Celis ${ }^{1, a}$, Nathalie Valle ${ }^{2, a}$, Jacques Lacaze ${ }^{3, b}$, \\ Ingólfur Thorbjornsson ${ }^{4, \mathrm{c}}$, Birgir Johannesson ${ }^{5, \mathrm{c}}$, JonThor Thorgrimsson ${ }^{6, \mathrm{~d}}$, \\ Bojan Podgornik ${ }^{7, e}$, Joze Vizintin ${ }^{8, e}$ \\ a Department "Science and Analysis of Materials" (SAM), Centre de Recherche Public-Gabriel \\ Lippmann 41 rue du Brill, L-4422 Belvaux, Luxembourg. \\ ${ }^{\mathrm{b}}$ CIRIMAT, Université de Toulouse, ENSIACET, 31432 Toulouse cedex 4, France \\ ${ }^{c}$ Innovation Center Iceland, Keldnaholt , 112 Reykjavik, Iceland. \\ d Malmsteypa Thorgrims Jonssonar, Midhraun 6, 210 Gardabaer, Iceland. \\ ${ }^{\text {e }}$ CTTD, University of Ljubljana, Bogisiceva 8, SI-1000 Ljubljana, Slovenia. \\ ${ }^{1}$ mayerling.martinez@cemes.fr, ${ }^{2}$ valle@lippmann.lu, ${ }^{3}$ jacques.lacaze@ensiacet.fr, ${ }^{4}$ ingo@nmi.is, \\ 5Birgirj@nmi.is, ${ }^{5}$ jonthor@malmsteypa.is, ${ }^{7}$ bojan.podgornik@ctd.uni-lj.si, ${ }^{8}$ joze.vizintin@ctd.uni-lj.si
}

Keywords: ductile iron, microstructure, local reinforcement, insert, wear

\begin{abstract}
The influence on the wear properties of ductile iron with Cr-containing steel inserts has been investigated before and after austempering. The microstructure of locally reinforced ductile iron, with and without an austempering treatment, has been characterized using optical microscopy, scanning and transmission electron microscopy and secondary ion mass spectrometry. The introduction of such inserts during casting leads to the precipitation of carbides $\mathrm{M}_{3} \mathrm{C}, \mathrm{M}_{7} \mathrm{C}_{3}$ and $\mathrm{M}_{23} \mathrm{C}_{6}$ ( $\mathrm{M}$ stands for $\mathrm{Fe}$ and/or $\mathrm{Cr}$ ) inside the inserts and to $\mathrm{M}_{3} \mathrm{C}$ and $\mathrm{M}_{7} \mathrm{C}_{3}$ in the region surrounding the inserts. After austempering, a partial dissolution of these latter carbides and transformation of the matrix to ausferrite occur. The wear properties of these materials have been evaluated under reciprocating sliding motion using cylinder-on-disc line contact configuration. The results of the present investigation show a better wear behavior of the reinforced material related to the microstructural changes observed.
\end{abstract}

\section{Introduction}

Ductile irons (DI) are essentially ternary Fe-C-Si alloys in which the concentrations of carbon and silicon vary typically from 3.5 to $3.9 \mathrm{wt} . \%$ and 1.8 to $2.8 \mathrm{wt} . \%$, respectively. Their typical as-cast microstructure consists of graphite nodules in a pearlitic, ferritic or pearlitic-ferritic matrix. DI can be used in the as-cast state or after heat treatment to generate a matrix microstructure and associated mechanical properties that are not readily obtained in the as-cast condition [1]. As an example, austempering provides a low cost material with an interesting combination of good mechanical properties, i.e. with significant ductility together with good wear resistance and fatigue strength [2]. Other methods such as plasma or laser melting, boriding or nitriding, have been used in order to improve the surface wear resistance of DI [3-6]. The possibility of both surface and sub-surface reinforcement has already been mentioned [7-9], and the as-cast microstructure of parts with $\mathrm{Cr}-$ containing steel inserts has been described recently [10]. In the present work, the focus is on the characterization of the microstructure and the study of wear properties of such DI parts before and after austempering. Its aim is to understand better the relationship between wear properties and microstructural changes induced by the local reinforcement and the austempering treatment.

\section{Materials and Methods}

The reinforced DI used in the present investigation has been elaborated with inserts made of stainless steel with 17-20 wt.\% Cr, about 8 wt.\% Ni and small amounts of $\mathrm{Mn}$ and Si. These inserts 
were cylindrical in shape and were appropriately located in the mould cavity that was later filled with a melt corresponding to an unalloyed standard DI (C: 3.7-3.9 wt.\%, Si: 2.7-2.8 wt.\%, Mn: 0.12-0.16 wt. \%, Mg: 0.03 wt\%, Cu: 276-426 ppm, Ni: 268-345 ppm, P: 219-265 ppm, S: 109-110 ppm, Mo $<10 \mathrm{ppm}$ ). Their thickness (typically $1-2 \mathrm{~mm}$ ) and size (typically $5-10 \mathrm{~cm}$ ) depend on the geometry and size of the component being cast (see an example on fig.1). The distribution of inserts in the mould cavity depends entirely on the wear load of the component and inserts are placed only where high wear resistance is required. Process parameters such as thickness of the inserts or superheat of the melt before pouring in the mould have to be adjusted to the size of the cast parts so as to ensure partial dissolution of the inserts before solidification of the cast iron. It has been shown that with a right combination of temperature and composition of the melt, appropriate alloying elements and thickness of component, parts can be successfully cast with such local reinforcement [8]. For the wear test, a particular part was prepared with cylindrical inserts (diameter: $2.5 \mathrm{~mm}$; distance between 2 inserts: $5 \mathrm{~mm}$ ) equally distributed and positioned perpendicular to the intended sliding direction. Samples were machined out from this part, one set was studied in the as-cast state (labelled RDI), whereas another set was subjected to austempering before characterization (labelled ARDI). Austempering consisted of two stages: heating to and holding at $900^{\circ} \mathrm{C}$ for 60 minutes followed by a quench to $300^{\circ} \mathrm{C}$ and holding at that temperature for 75 minutes before air-cooling.

Sample preparation for optical metallography was carried out using standard techniques. The surface of the samples was polished down to $1 \mu \mathrm{m}$ using a diamond paste before etching using either $4 \%$ Nital $(96 \%$ in volume of ethanol and $4 \%$ of nitric acid) or Glyceria also named Villela (3 parts by volume of glycerol, 2 parts of hydrochloric acid and 1 part of nitric acid). Scanning electron microscopy was performed with a Leica Stereoscan $430 \mathrm{i}$ operating at $20 \mathrm{kV}$. Chemical analyses were carried out in the SEM using an energy dispersive spectroscopy (EDS) system on polished samples. The microscope was also used to differentiate the phases present by means of their chemical contrast. The distribution of carbides in the region close to the interface between inserts and the DI was also investigated with a CAMECA NanoSIMS 50 instrument operated with a Cs primary source at an energy of $16 \mathrm{keV}$ in order to analyze $\mathrm{Cr}$ as $\mathrm{CrC}^{-}$ions. Microstructure observations and electron diffraction for phase determination were carried out by transmission electron microscopy with a LEO 922 OMEGA operating at $200 \mathrm{kV}$ as described elsewhere [10].

Tribological properties were investigated under reciprocating sliding motion. In order to measure average wear rate, taking into account several inserts, cylinder-on-disc line contact configuration was selected. In this facility, a hardened 100C6 steel cylinder $(\phi 10 \times 14 \mathrm{~mm} ; 62 \mathrm{Hrc})$ is loaded against a fixed reinforced DI specimen (Fig. 2). Before each test both the cylinder and the sample were ultrasonically cleaned in high purity benzene and then dried in air. Testing was performed at room temperature under dry conditions (relative humidity of $40 \%$ ) and in salt water $(34 \mathrm{mg} / \mathrm{l})$. The sliding stroke was set at $\mathrm{f}=8.8 \mathrm{~mm}$ with an oscillating frequency of $5.7 \mathrm{~Hz}$ (i.e. an average relative speed $\mathrm{v}_{\mathrm{s}}=0.1 \mathrm{~m} / \mathrm{s}$ ). For dry sliding a load $\mathrm{f}_{\mathrm{N}}=50 \mathrm{~N}$, corresponding to a maximum Hertz contact pressure $\mathrm{p}_{\mathrm{H}}=160 \mathrm{MPa}$, was used and a total sliding distance of $100 \mathrm{~m}$ (5.700 cycles) was achieved. For salt water lubricated conditions, the load was increased to $f_{N}=200 \mathrm{~N}\left(p_{H}=320 \mathrm{MPa}\right)$ and the sliding distance changed to $720 \mathrm{~m}$ (41.000 cycles) The loads applied were selected in such a way that measurable wear was achieved in reasonable time. Note that pressures in the range of 100-400 $\mathrm{MPa}$ are also typical for machine components operating under sliding conditions. During testing, the coefficient of friction, i.e. the friction force divided by the normal force, was monitored continuously as a function of the number of cycles and the wear volume was determined at the end of the test using a gravimetric technique. Each test was carried out three times and the average values are presented together with the standard deviation.

\section{Results and Discussion}

Microstructure. Fig. 1 shows a schematic representation of the material with inserts of stainless steel fixed inside the cast material. Due to the partial dissolution of the inserts during casting, a flux of elements, mainly chromium, goes from the steel to the melt while some carbon enters the insert. 
This leads to a gradual composition change of the melt around the insert and accordingly results in a microstructure gradient from the insert surface to the bulk DI. This region will be afterwards named the transition zone. This transition zone is characterized by the presence of $\mathrm{M}_{7} \mathrm{C}_{3}$ and $\mathrm{M}_{3} \mathrm{C}$ carbides that appear because of the high chromium level released by the dissolution of the insert. In addition, carbon intake in the insert leads to the formation $\mathrm{M}_{3} \mathrm{C}, \mathrm{M}_{7} \mathrm{C}_{3}$ and $\mathrm{M}_{23} \mathrm{C}_{6}$ carbides as described previously [10].

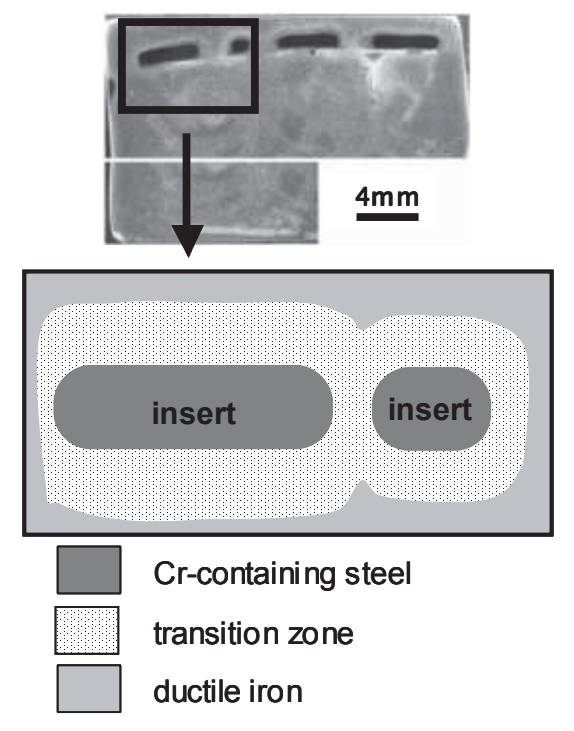

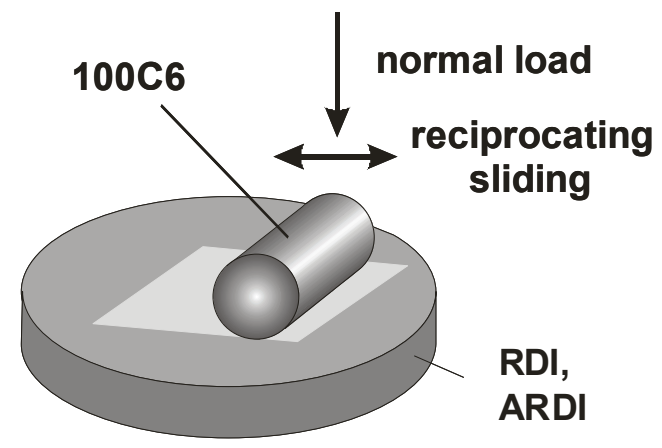

Fig. 2. Tribological test setup.

Fig. 1. Optical image of a RDI sample and schematic representation of the transition zone in the DI reinforced with steel inserts.

The transition zone in RDI material stretches out over $2 \mathrm{~mm}$ from the edge of the insert. Near the insert, it is composed of pearlite, carbides and small graphite nodules. Further away from the insert the nodule size increases, the carbide density diminishes and ferrite appears as a constituent of the microstructure (Fig. 3-a). Two distinct types of carbides have been distinguished on backscattered electron images in the SEM as shown in Fig. 4-a, and electron diffraction showed the presence of $\mathrm{M}_{3} \mathrm{C}$ and $\mathrm{M}_{7} \mathrm{C}_{3}$ carbides [10]. Fig. 5-a illustrates the bulk microstructure of the as-cast DI.

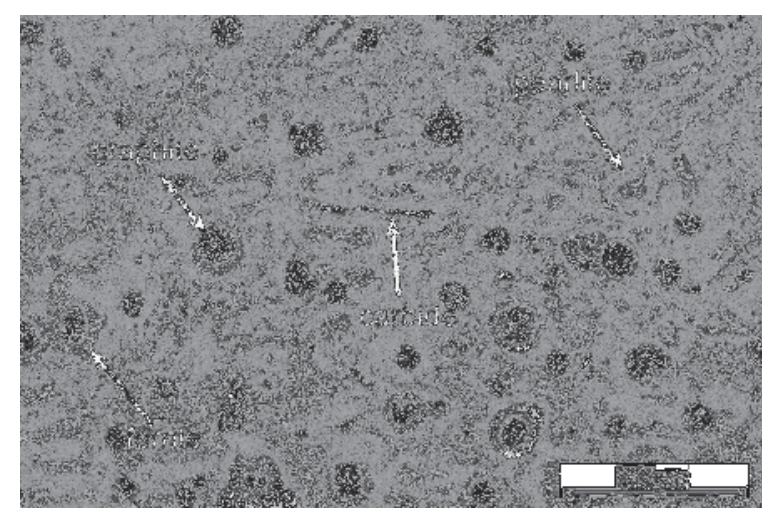

(a)

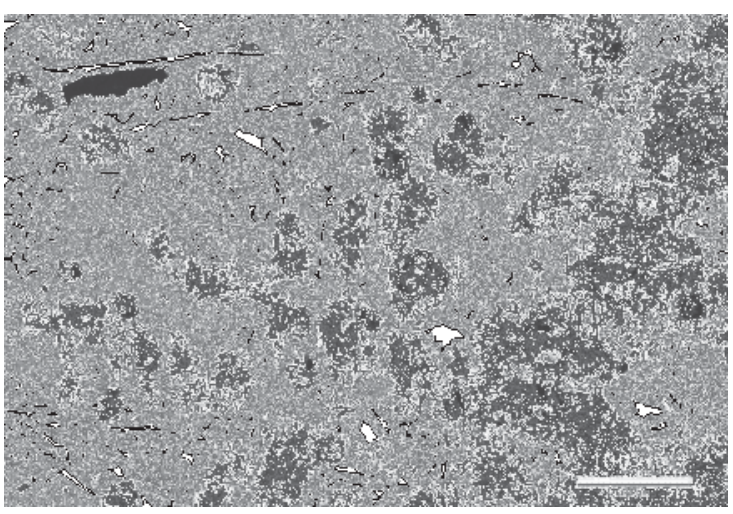

(b)

Fig. 2. Optical micrographs showing the transition zone in: (a) RDI and (b) ARDI samples after etching with $4 \%$ Nital.

After austempering, two main changes in the microstructure of the transition zone could be noticed: a partial dissolution of carbides, principally the $\mathrm{M}_{7} \mathrm{C}_{3}$ type, in some regions near the interface (Fig. 4-b) and, as expected, the transformation of the matrix to ausferrite (Fig. 3-b). The dissolution was only detected near the interface. The nature of the carbides, determined by electron diffraction studies, remained the same as in the as-cast state: $\mathrm{M}_{7} \mathrm{C}_{3}$ in dark contrast and $\mathrm{M}_{3} \mathrm{C}$ in light contrast (Fig. 4-b). The matrix of the bulk DI was also transformed to ausferrite (Fig. 5-b). 


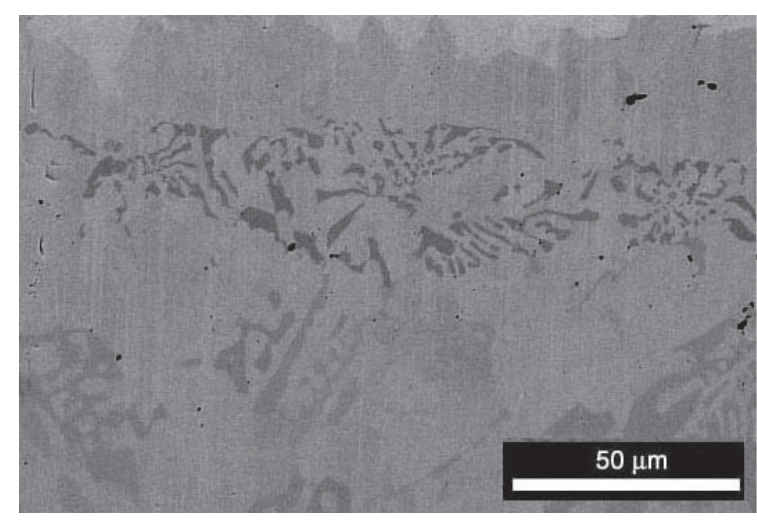

(a)

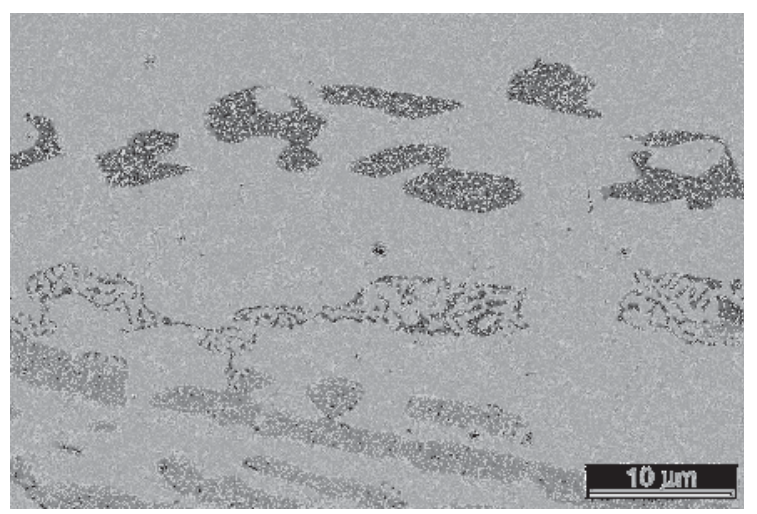

(b)

Fig. 4. Backscattered electron image showing two types of carbides in the transition zone: (a) before (RDI sample) and (b) after the austempering process (ARDI sample).

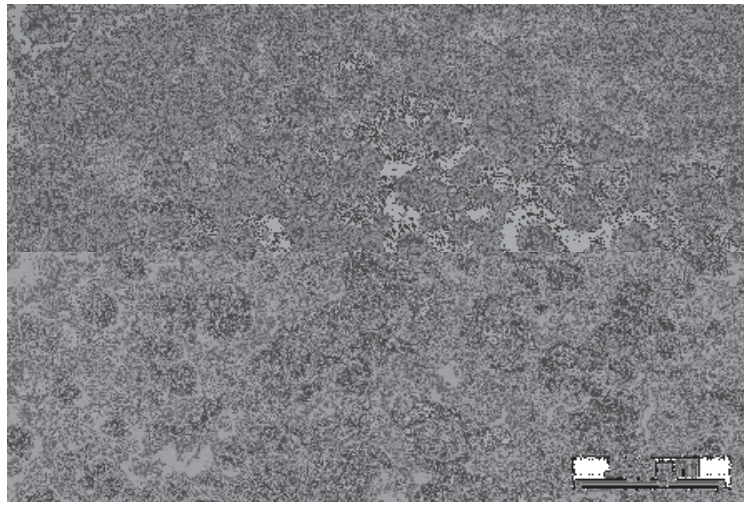

(a)

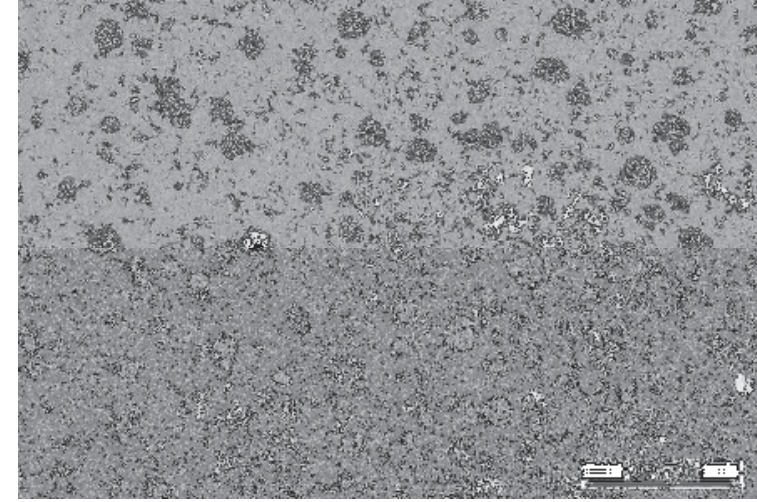

(b)

Fig. 5. Microstructure of RDI (a) and ARDI (b) samples far from the inserts.

Edge of the insert

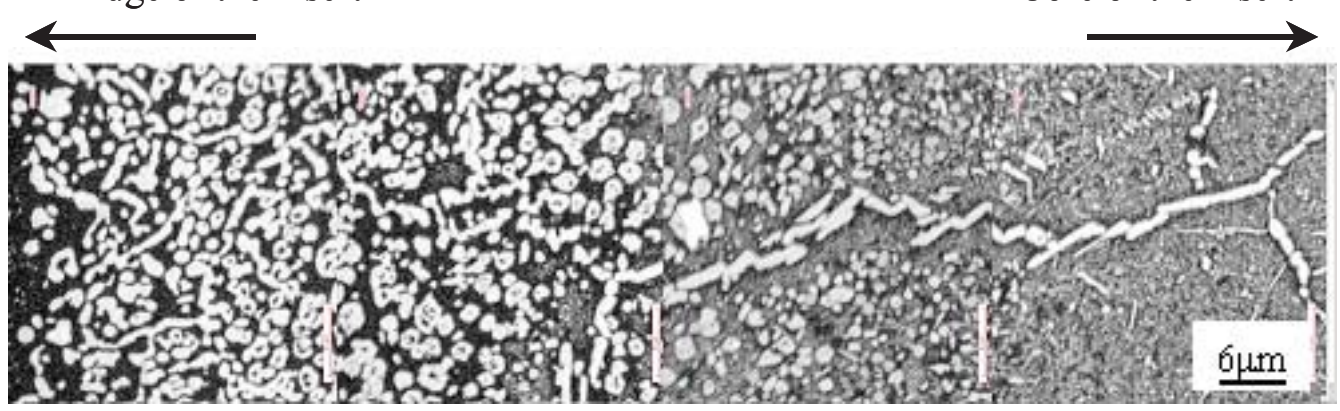

$\mathrm{M}_{7} \mathrm{C}_{3}$

$\mathrm{M}_{23} \mathrm{C}_{6}$

Fig. 6. $\mathrm{M}_{7} \mathrm{C}_{3}$ carbides visible on ${ }^{52} \mathrm{Cr}^{12} \mathrm{C}$ NanoSIMS images near the interface insert/transition zone of the ARDI sample. White contrast represents highest concentrations of the element while black contrast represents lowest concentrations.

Fig. 6 shows a NanoSIMS image acquired on an insert of an ARDI sample showing the microstructure evolution from the surface of the insert to its core. There is an ample inter- and intragranular precipitation of carbides of various compositions and morphologies up to $200 \mu \mathrm{m}$ from the insert/transition zone interface, while carbides are also present along grain boundaries up to the core of the insert. These carbides $\left(\mathrm{M}_{3} \mathrm{C}, \mathrm{M}_{7} \mathrm{C}_{3}\right.$ and $\left.\mathrm{M}_{23} \mathrm{C}_{6}\right)$ have already been described in detail for the as-cast materials [10], and remain unchanged after heat treatment. Most of the matrix in the insert remained in the form of austenite, except for a narrow area at the insert/transition zone interface where the martensite observed in the RDI sample has transformed into ausferrite after 
austempering. Although the interface insert/transition zone is not well marked, the same scarce carbides were found close to this interface in the ARDI sample as in the RDI one [10]. Further in the insert, ring-shaped $\mathrm{M}_{7} \mathrm{C}_{3}$ carbides already observed in the RDI sample are again noticed. Closer to the core of the insert, intragranular $\mathrm{M}_{23} \mathrm{C}_{6}$ type carbides that can be as small as $50 \mathrm{~nm}$ are observed.

Tribological Properties. The average value of the coefficient of friction was evaluated over the 5.700 or 41.000 sliding cycles. From the wear volume measured after the test, wear rate was calculated as the wear volume divided by normal load and sliding distance. The results for bulk DI, RDI and ARDI materials are shown in Fig. 7-a for dry sliding and in Fig. 7-b for salt-water lubricated conditions. Under dry sliding DI with a hardness of $250 \mathrm{HV}$ shows more or less stable friction with an average value of the coefficient of friction of about 0.6 . However, after $100 \mathrm{~m}$ of sliding, a very high wear volume of $10.6 \mathrm{~mm}^{3}$ and wear rate of $2.1 \times 10^{-3} \mathrm{~mm}^{3} / \mathrm{Nm}$ were measured, as shown in Fig. 7-a. Analysis of contact surfaces (Fig. 8) revealed extensive abrasive wear accompanied by a high degree of plastic deformation. Compared to DI, RDI shows more unstable friction with larger fluctuations and a higher average coefficient of friction at about 0.65 . On the other hand, its wear volume and wear rate have dropped by a factor of 10 , down to $0.8 \mathrm{~mm}^{3}$ and $1.6 \times 10^{-4} \mathrm{~mm}^{3} / \mathrm{Nm}$, respectively (Fig. 7-a). Increased friction and reduced wear is due to increased hardness of the reinforcement areas, showing 10-20\% higher hardness than DI (300-350 $\left.\mathrm{HV}_{0.1}\right)$ as measured by Vickers micro-hardness. It thus appears that the load is carried by the reinforced part of the surface while abrasive wear is concentrated around reinforcement islands, as shown in Fig. 9. Combining reinforcement and austempering (ARDI) resulted in reduced hardness of the reinforced areas $\left(\sim 300 \mathrm{HV}_{0.1}\right)$ and consequently in a slightly increased wear rate as compared to RDI at $4 \times 10^{-4} \mathrm{~mm}^{3} / \mathrm{Nm}$ but still much lower than that of DI. Additionally, austempering of the reinforced DI led to a slightly lower ( 0.6) and more stable friction coefficient, which is comparable to DI.
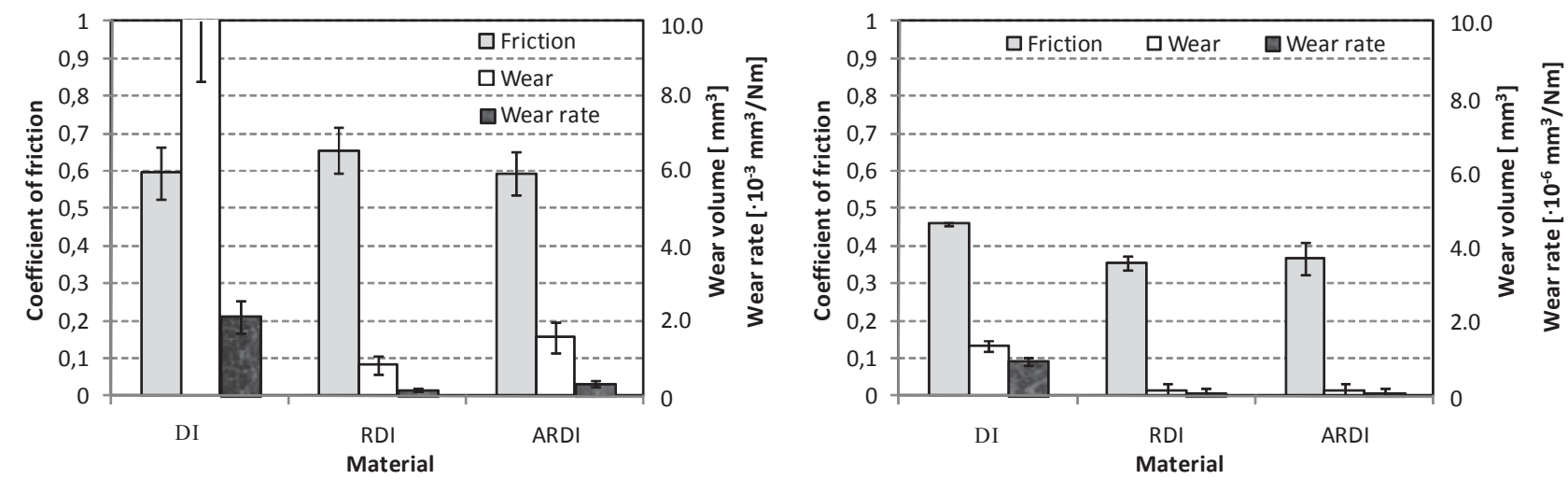

Fig. 7. Average friction coefficient, wear volume and wear rate of DI, RDI and ARDI samples tested under (a) dry sliding and (b) salt-water lubrication. Scatter bars show standard deviation of test results.

A change from dry to salt-water lubricated conditions led to a lower friction coefficient and greatly reduced wear of DI. As-cast DI shows stable friction with an average value of the coefficient of friction of 0.45 and a wear volume of $1.3 \mathrm{~mm}^{3}$ after $720 \mathrm{~m}$ of sliding (wear rate $\mathrm{k}=9.25 \cdot 10^{-7} \mathrm{~mm}^{3} / \mathrm{Nm}$ ). Reinforcement of DI does not only improve wear resistance in salt-water lubricated conditions (wear volume $\mathrm{W}=0.15 \mathrm{~mm}^{3}$, wear rate $\mathrm{k}=1.0 \cdot 10^{-7} \mathrm{~mm}^{3} / \mathrm{Nm}$ ), but it also leads to a lower coefficient of friction (about 0.35 ), with RDI and ARDI materials giving very similar results as shown in Fig. 7-b. 


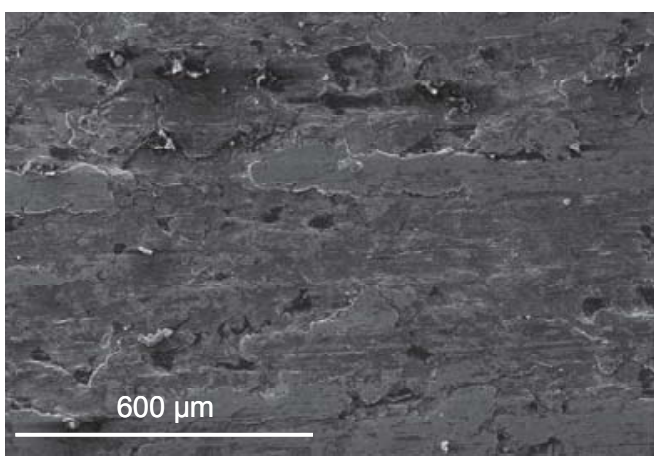

Fig. 8. Wear track of DI after $100 \mathrm{~m}$ of dry sliding

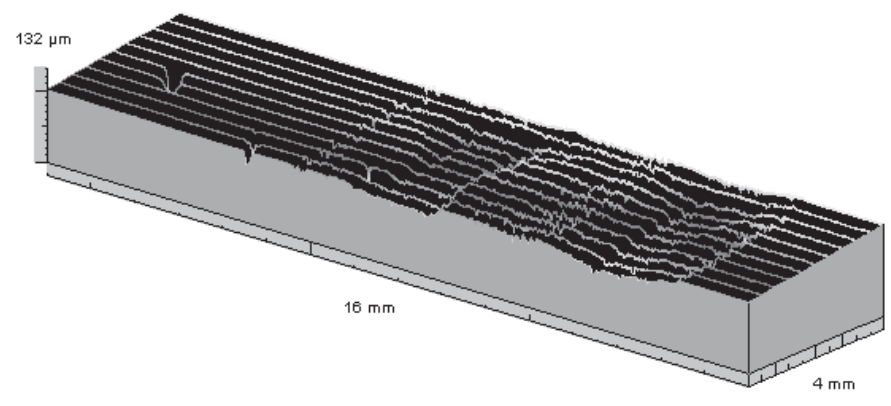

Fig. 9. Topography of RDI after $100 \mathrm{~m}$ of dry sliding

\section{Conclusion}

The introduction of $\mathrm{Cr}$-containing steel inserts during casting leads to the precipitation of carbides $\mathrm{M}_{3} \mathrm{C}, \mathrm{M}_{7} \mathrm{C}_{3}$ and $\mathrm{M}_{23} \mathrm{C}_{6}$ inside the inserts and to $\mathrm{M}_{3} \mathrm{C}$ and $\mathrm{M}_{7} \mathrm{C}_{3}$ in the region surrounding the inserts. These carbides are known to provide good resistance to abrasive wear because of their high hardness [11]. Through the formation of these carbides, a hard transition zone is formed around the inserts that carries the load under sliding motion. At the same time, the softer surrounding area - the steel inserts and the bulk DI - are subjected to abrasive wear. Thus, the local reinforcement increases the load carrying capacity of the surface which results in more than 10 times better wear resistance of the DI. However, due to the presence of carbides and reduced graphite content in the contact zone, local reinforcement also leads to higher friction. The combination of local reinforcement of DI and austempering induces the transformation of the matrix into ausferrite and a partial dissolution of carbides, which results in a reduced load carrying capacity and consequently a higher wear rate. Nevertheless, austempered reinforced DI still shows considerably better wear resistance than normal DI and similar friction. In this way, austempering of reinforced DI combines friction properties of DI and wear resistance of the reinforced DI.

\section{Acknowledgements}

The authors wish to thank E. Lentzen, P. Grysan and B. El Adib for their helpful contribution to this work. This work was financially supported by the Fonds National de la Recherche de Luxembourg (DIWEAR project within the INTER - ERA-Net MATERA programme).

\section{References}

[1] J.R. Davis: in Cast Irons (ASM, Materials Park, OH, USA, 1996)

[2] R. Elliott: Cast iron technology (Butterworths, NY, USA, 1988)

[3] A. Amirsadeghi and M. Heydarzadeh Sohi: J. Mater. Proc. Tech. Vol. 201 (2008), p. 673-677

[4] J.H. Abboud, K.Y. Benyounis, A.G. Olabi and M.S.J. Hashmi: J. Mater. Proc. Tech. Vol. 182 (2007), p. 427-431.

[5] M.A. Béjar, W. Schnake, W. Saavedra and J.P. Vildósola: J. Mater. Proc. Tech. Vol. 176 (1996), p. 210-213.

[6] M. Heydarzadeh Sohi, G. Karshenas and S.M.A. Boutorabi: J. Mater. Proc. Tech. Vol. 153-154 (2004), p. 199-202.

[7] M. Qian, S. Harada, Y. Kuroshima and H. Nagayoshi: Mater. Sci. Eng. Vol. A208 (1996), p. 88-92.

[8] I.Ö. Thorbjörnsson and J.T. Thorgrímsson, international patent application under the PCT treaty. WO 2009/081420 (2009).

[9] I.Ö. Thorbjornsson, B. Johannesson, J.T. Thorgrimsson, submitted to Int. J. of Cast Metals Research.

[10] M. Martinez Celis, N. Valle, J. Lacaze, I. O. Thorbjornsson, B. Johannesson and J.T. Thorgrimsson, Int. J. Cast Metals Res., in press

[11] G.W. Stachowiak and A.W. Batchelor: Engineering Tribology (Elsevier, Amsterdam, The Netherlands, 2005). 